that the fungus is the direct cause of the progress and of the destructive operation of the malady, and that it is probable, though not so certain, that the spores germinate in the healthy stem, and actually produce the disease.

The last paper contains a description by Dr. Cohn of a plant which he has discovered in well-water at Breslau, and to which he has given the name of Crenothrix polyspora. The genus is new and is closely allied to Chamcesithon, being intermediate between that and Lyngyba. It would take too much space to describe the plant at length, for the particulars of which we must refer to the paper, in which will be found, moreover, some interesting observations upon the microscopical analysis of well-water in general. The Crenothrix was first noticed in water from a well at Breslau, in a part of the town notorious for the prevalence of typhus. It has been found also in other wells of bad reputation, but whether it has any injurious effect upon the health of the dwellers in the neighbourhood of the wells in question Dr. Cohn cannot venture to say.

It will be seen, from what has been said, that the periodical under notice is well deserving the attention of botanists and physiologists, and from the reputation of its editor there is every reason to hope that the scientific interest of future numbers may equal that of the present one.

F. CURREY

\section{OUR BOOK SHELF}

Matheran Fill, its People, Plants, and Animals. By

J.Y.Smith, M.D. (Edinburgh: Maclachlan and Stewart.) THIS is perhaps the first attempt that has been made to give a comprehensive account of the natural history of any particular spot in our East Indian possessions, and we welcome this little book as a sample of what may be accomplished by residents there in the midst of their official occupations. The undertaking is worthy of all praise, and, as far as it goes, it is a valuable contribution to the ethnology and natural history of India, and will no doubt be the groundwork for further research, and lead to other similar works.

The hill of Matheran is within twenty miles of the coast of Bombay, it is basaltic, and rises in the centre of a vast plain to the height of about 2,600 feet, it is precipitous on all sides, flat on the summit, which has an area of about five square miles, and is clothed with luxuriant vegetation ; it is, in short, one of the most charming spots in India. In less than three hours one can be transported from the heat, dust, and noisy traffic of Bombay to what appears to be another world, where the body is refresbed and invigorated by the pure mountain air, and the spirit soothed by the beauty of verdant foliage, the cheerful music of feathered songsters, scenery grand and picturesque, and the general repose of nature. To the naturalist Matheran opens a grand volume to him, the little plateau has an air of enchantment, and he has spread out before him in the most attractive form objects which will supply him for even years with delightful and instructive occupation without the toil and exposure of long journeys. To such Dr. Smith's account of the more prominent objects to be met with will therefore be a valuable boon, and, indeed, to all lovers of nature who may visit the place. Let the home botanist imagine himself in a pretty little cottage on Matheran, with no less than seventy-five flowering trees and shrubs within a mile of his residence ; not to mention climbing plants, creepers, herbs, parasites, and ferns in abundance. As the author is now returning to the East, we hope he will have opportunities of extending his interesting observations, especially on the birds and insects. To the geologist, Matheran is an object of interesting study; he will there see that curious rock called laterite or iron stone clay, the nature of which has been so much disputed, capping the great basaltic formation (to use a homely phrase) like the sugar on a Christmas cake, and if he extends his observations to the north and south, he will find the same capping on other hills, thirty to sixty miles distant, while no trace of it exists in the interval between. To what bold speculations does this fact give rise? Did this laterite once cover the whole country as with a mantle, and are present appearances due to a vast denudation of hard trappean rock 2,000 to 3,000 feet deep?

We are glad to find natural history included among the subjects for Indian Civil Service examinations, for hitherto this class of Europeans in India have contributed comparatively little to our knowledge of that wonderful land "where all, save the spirit of man, is divine."

A Voyage Round the World. By the Marquis de Beauvoir. 2 vols. (Murray, 1870.)

THIS is the gossiping journal of a young companion of the Duc de Penthièvre, son of the Prince de Joinville, often amusing and spirited, but of little permanent value, We have the usual exaggerations of a novice in the tropics. At Batavia he speaks of "this torrid temperature of $104^{\circ}$ in the shade," a degree of heat never experienced by the present writer during many years' residence in those regions. The author's scientific attainments may be estimated by his account of his visit to the Melbourne Museum, when he makes Prof. MacCoy speak in this fashion :- "The stratum of alluvial soil covering the crust of primitive rocks, which formed round the earth while it was still in a liquid and incandescent state, possesses the same specific type of animal life that characterises the ancient strata of Wales, Sweden, and North America. Then come soils identical with those of these countries, schist and fossil rocks; thus Canada, Scotland, and the province of Victoria have all passed through the same form of existence at this remote period." The countries described are Australia, Java, Siam, and Canton, and the whole journey occupied about six months.

A. R. W.

The Student and Intellectual Observer. A Quarterly Journal of Science, Literature, and Art. Vol. 5. (London : Groombridge and Sons.)

THE volume now before us is in every way worthy of the reputation of its predecessors. Four papers on poison are contributed by Mr. F. S. Barff, and Dr. Carpenter contributes two interesting papers on the "Deep Sea," the first on its physical, and the second on its biological condition. The author's experience in these matters, owing to his connection with recent explorations, make the papers the more interesting, because they are the words of an actual and accurate observer. Dr. Collingwood also gives a very readable paper on a kindred subject, " The Sargasso Sea and its Inhabitants," in which the Sargassum or Gulf-weed comes in for a good share of attention, being, as it is, the home of multitudes of Polyzoa, Polyps, Crustacea, Molluscs, and similar creatures. Mr. Shirley Hibberd talks about Cycads under the very misleading title of "Sago Palms." At one time the Sago of commerce was supposed to be the produce of the Cycads, but now we know that the bulk of this useful article is yielded by two or more species of Sagus, true palms ; it is, to say the least, advisable that an old term proved to have been wrongly given, should not be perpetuated. The author, however, does attempt to qualify its use in the following sentence :- " By 'Sago Palms' is to be understood the great group of gymnospermous plants, of which the Cycads and their allies are representatives, a group possessing powerful morphological relations, and, of course, a correspondence within certain limits in all their biological characteristics." The volume contains many other interesting papers in various branches of science, and we conclude this short notice by wishing well to an old-established monthly in its new quarterly form. 